\title{
sciendo
}

\section{TRANSLATION AS A CATALYST IN THE DEVELOPMENT OF MODERN CHINESE LEGAL LANGUAGE}

\section{DEBORAH CAO, Professor}

\author{
School of Humanities, Languages and Social Science \\ Griffith University, Australia \\ Email: d.cao@griffith.edu.au
}

ORCID: https://orcid.org/0000-0002-0775-8864

\begin{abstract}
This paper focuses on the translation of legal language and the development of modern Chinese legal language as a translated legal language. It first describes the historical contexts in which China underwent enormous and unprecedented social and political changes including changes to law in the late 1800s and early 1900s. It then discusses how translation played an important catalyst role in introducing Western law, legal practices, legal concepts and terminology in the emerging modern Chinese legal language as we know it today, and in the process, lent a helping hand in negotiating China's transition to modernity through translation and creating a new legal language and legal system. It also considers the issues in translingual and cross-cultural communication and understanding translated Chinese legal language.
\end{abstract}

Keywords: Chinese legal language, Chinese law, modernity in China, legal translation, legal terminology, legal concept 
Deborah Cao: Translation as a catalyst in the development...

\section{翻译在现代中国法律语言发展中的催化作用}

摘要: 本文论述法律语言翻译以及现代中国法律语言作为一种翻译法律 语言的演变发展。文章首先描述 1800 年代末和 1900 年代初期的中国经 历的前所未有的巨大社会和政治变革的历史背景, 然后探讨翻译如何在 引入西方法律、法律实践和法律概念和词汇和中国现代法律演变中起到 的重要的催化作用, 创造出了新兴的现代中国法律语言, 并在此过程中, 通过建立新的法律语言和词汇和法律体制协助中国向现代社会的过渡。 最后文章还考虑了跨语言和跨文化交流以及如何理解和诠释中国法律语 言等问题。

关键词: 中国法律语言, 中国法律, 中国现代性, 法律翻译, 法律术语, 法律概念

\section{Introduction}

A story was told from the 1940s in China. An American official delegation was visiting China. A Chinese host in conversation asked about the American 'Empire' and its 'Emperor' to the amazement of the American visitors. It turned out that the Chinese host was under the impression that the U.S.A. was an empire and it had an emperor as the head of state because the word 'President' in English had been mistakenly translated as huangdi (皇帝 emperor) as an equivalent (Cao $2007)^{1}$. Now, in more recent times, in a reverse situation, a question has been raised as to the accuracy of the translation of the title for the Chinese head of state into English. It is noted that in all the major American and other English language media outlets, the Chinese head of state is invariably referred to as China's 'President', but it may sound bizarre to some because China has no president (Fish 2019) ${ }^{2}$. Xi Jinping, the current Chinese Head of State, officially holds three key titles: General Secretary of the Central Committee of the Communist Party of China, Chairman of

\footnotetext{
${ }^{1}$ The English word 'president' was believed mistakenly to be the equivalent of the Chinese guojun (monarch) in China in the early days, and it has since been translated as zongtong (president). Similarly, 'administration' was translated as chaoting (imperial court), which is now translated as xingzheng.

2 See https://slate.com/news-and-politics/2019/08/xi-jinping-president-chairmantitle.html
} 
the Central Military Commission, and Chairman of the People's Republic of China (PRC). In Chinese, the third title uses zhuxi 主席, which means 'chairman', but this title has been translated, or mistranslated, as 'president' in English. As pointed out (Fish 2019), just like no one in the United States calls the President of the U.S.A. the chairman of America, no one in China calls Xi or his predecessors President. In China, Xi and his predecessors are always called Chairman in Chinese, but he is now called Mr President in English. One may say that this is just a title, a minor point of nomenclature. However, as suggested, this mistranslation is pernicious and problematic because it allows people or more precisely the Chinese to tell two radically different stories (Fish 2019). In China, General Secretary and Chairman Xi Jinping rules over a tightly controlled, illiberal system, but internationally, while President Xi Jinping is portrayed as an advocate for globalization, openness, and free trade, and this also obscures what is unique about China's authoritarian political system, so Xi should be called Chairman, a title he actually holds, and a title he deserves (Fish 2019).

The two examples, although from two different eras, illustrate the kind of problems and sometimes profound misunderstandings that translation, particularly, the translation of institutional terms, can cause. In this essay, the roles of translation of law and legal terminology in modern Chinese legal language are examined. The focus is on the translation of legal language from the West into Chinese during the transitional period from traditional to modern society and its enabling roles in the development and evolution of modern Chinese law and legal language. It also considers the issue in translingual and cross-cultural communication and understanding translated language in law.

\section{Translation and introduction of Western law laying the foundation for modern Chinese law and legal language}

Translation has always played an important part in the Chinese cultural evolution throughout history. Contact and exchange between China and the West in the intellectual sphere in the late nineteenth and early twentieth centuries were instrumental to the long modernization process of China in transition, often mediated through translation. Legal 
translation was a relatively late comer but critical and fundamental to the development of modern Chinese law and legal language.

Chinese law is one of the oldest legal traditions in the world. Traditional Chinese law refers to the laws, legal rules, and legal cultures of imperial China up to 1911 when the last imperial dynasty ended. For the most part of the history of traditional China, its legal system and laws were based on the Confucian philosophy of social control through moral education as well as the Legalist emphasis on codified law and criminal sanction (Cao 2004, 2018). In modern China after the end of the imperial dynasties, the Republic of China adopted a largely Western-style legal code in the 1920s and 1930s, with the core of modern Chinese law heavily influenced by the European civil law, and later socialist law, in additional to traditional Chinese thoughts. The establishment of the People's Republic of China in 1949 and the period up to 1960s saw influence from the former Soviet Union and its system of socialist law. Since the end of the disastrous and chaotic Cultural Revolution (1966-1976), especially since the reform and opening policy in the 1980s, Chinese law has been influenced by Western law. In the past two hundred or so years, modern Chinese law in both formation and transition can be considered a hybrid in many ways, but it has always retained the underlying Chinese perspective and mindset towards law in its classical tradition. After all, the Chinese language functions as the constant thread and the instrument of communication negotiating between the past and the present (Cao 2018). In this respect, translation plays a very important role. The transplant or borrowing of Western laws in China was assisted and facilitated through the medium of translation. It is proposed that translation plays an important role as a catalyst in translating and introducing Western laws into Chinese and creating a modern Chinese legal language and legal vocabulary. This facilitated, motivated, and enabled the creation of new meanings and, more importantly, new legal realities in the Chinese society in transition. 


\subsection{Historical backdrop for law reform and learning from the West}

First of all, a few words about the background and context for modernizing or transforming the traditional Chinese legal order in the late $19^{\text {th }}$ and early $20^{\text {th }}$ centuries.

China's push towards modernization began in the late Qing Dynasty. In the late $19^{\text {th }}$ century, there was a desperately felt need and urgency in China for modernization, among many in the imperial government and the intellectual circles. Here modernization is used in a broad sense to refer to various types of social change and their related issues or problems, entailing multidimensional scientific, technological, political, economic, institutional factors, and it also refers to intangible (or non-material) factors of social change, such as values, modes of thinking as well as the historical, cultural and spiritual heritage (Soo 1989). Thus, China's modernization is seen as a historical process of transformation from a traditional to a modern society, which began with the advent of modern China in mid- $19^{\text {th }}$ century with social change, both evolutionary and revolutionary, in all major areas of Chinese society, and continuing today (Soo 1989).

In the mid-19th century, China lost two Opium Wars (18391842, 1856-1860) to the United Kingdom (U.K.) and France, which resulted in the conclusion of various treaties between China and Western powers, including the Treaty of Nanking between China and the U.K. after the first Opium War (see Fairbank 1940; Wong 2018). The Treaty of Nanking was branded as having begun a century-long victimization of the Chinese people (Wong 2018) ${ }^{3}$. It was the first of many unequal treaties that China signed during this period, and with them, came the imposition of extraterritoriality and loss of territorial sovereignty among other things (including the cession of Hong Kong as a British colony). These were seen as a major devastating national humiliation that the Chinese bitterly felt and still feel today. The imperial officials and the intellectual class began to debate and then accepted the need for change as a matter of urgency and national salvation. In particular, there were fierce debates as to how to change

\footnotetext{
${ }^{3}$ For images of the Chinese version of the Treaty of Nanking, see Wong (2018), taken from the digitized images of the original Chinese copy of the Treaty of Nanking held in the National Palace Museum Library in Taipei, Taiwan.
} 
and transition China to modernity while retaining Chinese traditional values and culture. It was felt necessary to learn from the West, but Western technology alone was deemed insufficient. At the same time, it was admitted that the Chinese traditional system was hindering China's progress and modernization and its ability to deal with the West and to deflect the threat posed by them. Then came the idea that borrowing from the West and Japan for economic development or modernization while preserving the essence of Chinese culture, the famous notion of zhong ti xi yong, that is, 'Chinese learning as the essence and Western learning for application', first proposed by Feng Guifen (1809-1874), a Qing scholar, after the Second Opium War. Feng wrote: 'What could be better than to take Chinese ethical principles of human relations a and Confucian teachings as the foundation $(t i)$ and supplement them with the techniques (yong) of wealth and power of the various nations?" ${ }^{4}$ The ideas were further elaborated on by Zhang Zhidong (1837-1909), an influential Qing official. Then zhong ti xi yong became a popular slogan during much of the transitional period, especially widely accepted among intellectuals. The basic idea was that China could achieve its self-strengthening and modernization through learning and borrowing Western technology and other advanced knowledge, while retaining the core Confucian or traditional Chinese moral and cultural values ${ }^{5}$. As is noted, with the Self-Strengthening Movement or Westernization Movement (1861-1895), and the debate over 'Chinese essence and Western application', 'the Chinese experience entailed a protracted struggle through which the Chinese forfeited many of their culturally distinctive features in the name of modernization and mobilization' (Wong 2018), and for our purpose, reformed and forfeited some of the features in traditional Chinese law that were incompatible with modern society.

\footnotetext{
${ }^{4}$ For Feng's ideas in English, see http://afe.easia.columbia.edu/ps/china/feng_guifen_western_learning.pdf

${ }^{5}$ There was a Self-Strengthening Movement (ziqiang yundong), also known as the Westernization Movement (yangwu yundong, 1861-1895), when institutional reforms were implemented during the late Qing dynasty following the defeat of the Opium Wars. Previously, another well-known related idea was 师夷长技以制夷 (shi yi chang ji yi zhi yi), literally, 'learning from the advanced technologies of the foreigners in the West in order to resist their invasion'.
} 


\subsection{Law reform and translation and introduction of Western law}

Of the debates and efforts to modernize China, law reforms and the need to establish a new or modern legal order with modern laws to deal with the West became a matter of urgent priority. As pointed out, after the Opium Wars, China felt compelled to come to terms with Western normative order and its fundamental assumption (Carrai 2017). As a direct and immediate result of the lost Opium Wars, extraterritoriality and loss of territorial sovereignty demanded by the Western countries in the treaties China signed meant foreigners and foreign entities in China would not be governed by Chinese law, and Westerners would not accept the jurisdiction of the Chinese imperial laws which were deemed barbaric ${ }^{6}$, forcing the imperial Qing government to initiate fundamental change to the law of the land and law reforms (Wu 2013). It was also believed that those unequal treaties were signed by China partly out of expediency and partly because Qing officials did not even understand international law and the long term consequences of those treaties. Starting from around 1900, the Qing government started various law reform programs to change the traditional Chinese legal codes to adopt and adopt modern Western style laws. A series of government initiated and sponsored efforts and programs were undertaken towards this end. Among them, the training of Chinese translators and interpreters, the translation of foreign works into Chinese, particularly, Western works in social sciences and laws, establishment of educational institutions and pollical and law reforms (He 2004b). More specifically, Shen Jiaben (1840-1913), a late Qing Chinese official and jurist, became the Secretary of Enactment in charge of translation of foreign laws and codification of new laws. He later served as the Minister of Justice who was responsible for the 1905 revision of the Qing Code, abolishing much of the traditional Chinese criminal punishment such as various cruel and inhumane forms of the death penalty including 'slow slicing' (lingchi) of condemned prisoners. The Imperial Law College in Beijing was established in 1906. As a result, a large number of Western legal codes and legal scholarly works

\footnotetext{
${ }^{6}$ At the time of the Chinese-Western contacts and interactions around the $19^{\text {th }}$ century, the Chinese imperial officials called Westerners 'barbarians' ( $y i$ ), while Westerners regarded the Chinese, especially some aspects of the Chinese criminal laws, as barbaric.
} 
were translated into Chinese, introducing the Western legal system, legal science, and laws to China (He 2004b).

The introduction and translation of Western legal texts into Chinese is believed to have been started under an imperial official, Lin Zexu (1785-1850), around 1839 (He 2001). (For detailed discussion of Chinese translation of foreign legal works during the late Qing period, with a list of the major translated works, their translators and other publication details, see Tian and Li 2000). In 1839, Lin Zexu, a Qing imperial commissioner, organized and commissioned the translation of international law texts into Chinese by an American medical missionary Peter Parker (1804-1884) and a Chinese imperial interpreter by the name of Yuan Dehui (For Parker's translation activities in China, see Zhou Zhenhuan, 2000). Together, they translated sections of E. De Vattel's (1714-1767) The Law of Nations (Vattel 1863). The result was Wanguo lüli later published in Wei Yuan's (1794-1856) Hai guo tu zhi (Illustrated Treatise on the Maritime Countries) in 1847, which consisted of translations on various subjects from the West (see $\mathrm{He}$ 2001, 2004b; Svarverud 2001; W. Wang 1985). Hai guo tu zhi briefly touched on Western legal systems. This is believed to be the earliest piece of a Western legal text translated into Chinese (Chang 1950; Svarverud 2001). Then systematic introduction of Western law together with Western science and social science on a much broader scale followed with the establishment of Tongwenguan (Combined Learning College, or Peking Imperial College) in Beijing in 1862 for the purpose of disseminating Western knowledge. Tongwenguan was initially set up as a college for training Chinese translators and interpreters. It was later expanded to include the teaching of Western science and technology.

It was during his tenure in Tongwenguan that the American missionary and legal scholar, W.A.P. Martin (1827-1916), produced Wanguo gongfa 万国公法, the Chinese translation of Wheaton's Elements of International Law (Martin 1864; Wheaton 1916), under his Chinese name Ding Weiliang, regarded as the most influential and important first major translation of Western law into Chinese. Martin's translation of Wheaton's Elements of International Law (1864) has had profound and far reaching impact on the development of modern Chinese law, and the development of modern Chinese legal language (Cao 2004, 2017; He 2001). It was the first translation of a complete Western legal work on international law into Chinese. As pointed out, it introduced Western international law to China in terms of legal system, structure, 
contents, institutional principles, ideological concepts and conceptual terminology, bringing a new system of international law to the Chinese people (He 2001, 2004b). According to Biggerstaff, other Chinese translations of writings on international law published by Tongwenguan included the translations of de Martens' Guide diplmatique, Woolsey's International Law, Bluntschli's Droit international codifié, and an article by Martin on the practice of international law in ancient China, and also Faguo lüli, the translation of Code Napoléon, translated by Anatole Adrien Billequin (1826-1894, his Chinese name being Bi Ligan), and the translation of the Penal Code of Singapore. In short, from the time around the Opium Wars to 1989 (the failed Wuxu Reform that lasted one hundred days), the period represents the start of the translation of Western legal works into Chinese introducing Western legal thoughts to China.

Following this to around Xinhai Revolution (1911) which saw the overthrow of China's last imperial dynasty and the establishment of the Republic of China (ROC), a rapid progress was made in the translation of more foreign legal laws and legal works. In 1900, Liang Qichao (1873-1929), a jurist, historian, philosopher, and an influential intellectual figure in modern Chinese social and legal development, advocated the idea of borrowing from Western law as a fundamental policy for governance in China. In particular, he promoted the translation of Western political and legal works. Another influential and prominent scholar and thinker around this period was Yan Fu (18541921) who was also a major translator of Western law into Chinese. He translated, among others, Montesquieu's De l'esprit des lois (The Spirit of Laws) into Chinese. Ya Fu was known for his translation and introduction of Western thoughts to China including Darwin's theory of evolution. His other seminal translations around this period included Evolution and Ethics by Thomas Henry Huxley, The Wealth of Nations by Adam Smith, The Study of Sociology by Herbert Spencer, On Liberty by John Stuart Mill, and A System of Logic by John Stuart Mill ${ }^{7}$. The impact of these translated works extends far beyond their time in China's modern intellectual and social development including today.

In terms of the Chinese legal language, I suggest that the efforts in translation of Western law from the second half of the nineteenth century till the 1930s prepared the building blocks for modern Chinese

\footnotetext{
${ }^{7}$ Yan Fu developed his famous translation standards during this period: faithfulness, expressiveness, and elegance.
} 
legal language and Chinese law (Cao 2004). It is around this period that modern Chinese legal language started to take shape. Another distinctive and critically important aspect in the development of modern Chinese legal language and legal translation is the role and medium of the Japanese legal language (Cao 2004). Relevantly, Japanese law developed during the Meiji Period (1868-1914) involved in large part the Japanese translation of Continental European laws. Due to the closeness between the Chinese and Japanese writing systems, Chinese translators resorted to borrowing directly from the Japanese legal terms without the need to creating entirely new Chinese words on their own. This speeded up the translation process and this turned out to be very effective and efficient (see more in 2.3). Early modern Chinese dictionaries included Xin er ya, a dictionary published in 1903, with a section on politics and a section on law, explaining new political and legal terminology, and Han yi xin falü cidian (New Legal Dictionary Translated into Chinese) published in 1905 (Yu 2001: 24-66).

In terms of the development of modern Chinese law, in the history of legal translation in China, a noteworthy and significant area is the practice called yijie. Yijie literally means 'translation and introduction' or 'introduction through translation' (Cao 2004). This can refer to any types of translated texts, but in legal translation, 'introduction' includes not only introducing and describing foreign laws and legal systems, but more importantly, 'introduction' is also intended for making Chinese laws through transplanting foreign laws. Yijie was started towards the end of the nineteenth century, and was very significant from 1896 to 1936 during which period the Chinese absorbed and codified their version of Western laws, largely through the translation of Western laws and scholarly legal works (Henderson 1970: 158). Thus, the translation of foreign legal works and laws had a definite purpose, that is, to transplant or to create Chinese laws modelled on the foreign laws to replace the ancient Chinese laws that were deemed outdated and ineffectual in dealing with modern realities and other countries.

In short, by the 1920s and 1930s, the basic framework for a new Chinese legal order modelled on European Continental civil law was taking shape together with the newly created Chinese legal language. The vast amount of translation and lawmaking activities by the reform minded Chinese scholars and jurists in translating and introducing Western law to China were seminal in laying the foundation of modern Chinese law and modern Chinese legal language as we know it today. 


\subsection{Creating a new legal vocabulary in Chinese through translation}

It can be said that the broad framework was drawn up and the foundation for modern Chinese law was laid through translation and introduction of Western law and legal science around the turn of the last century. Now we look more specifically at the building blocks of that framework, that is, the actual words, the legal concepts, and other expressions that were translated into or created in Chinese during this formative era, how the early Chinese translators translated Western legal words and concepts, and how they mediated and facilitated cross-cultural communication in the process. This can throw some light not only on translation, but also on how language, culture, and ideas evolve and interact, and how diffusion of knowledge and values occur across national boundaries.

First of all, in the early translational activities of Western law, three main methods were used: the new words and foreign concepts were integrated into the Chinese language by way of using existing Chinese words, neologisms were created with new legal meanings, and direct borrowing. Most of the terms introduced then have now become established in the Chinese lexicon as an integral part of the Chinese legal language and political discourse. For instance, in the translated Wanguo gongfa (Elements of International Law) by Martin and his collaborators, many Western legal concepts, in particular international law concepts, were introduced into Chinese for the first time (see Chiu 1968; Henderson 1970; Liu 1995). In Wanguo gongfa two major translation methods were employed: creating neologisms and using existing Chinese terms for new legal meanings. For instance, newly created legal concepts and terms that were used for the first time in Chinese include zhuquan 主权 (sovereignty), minquan 民权(civil right), fayuan 法院(court), zeren 责任 (responsibilities, liabilities, duties), liyi 利益 (interest), renmin 人民 (people), guoti 国体(system of government), among others see $\mathrm{He}$ (2001); (He 2004a, 2004b); ( $\mathrm{Li}$ 1997). These were entirely new and foreign concepts and words to the Chinese then. They have since become an integral part of the Chinese language, and are some of the most commonly used words in Chinese legal, political and everyday language today. Most Chinese are not aware of their foreign origin. However, at the time of Martin's translation, due the large number of newly created words of various kinds with entirely foreign concepts and ideas and how 
laws were described, the translation was thought to cause verbal confusion and difficulty to comprehend to the Chinese. Martin and his translation team created other neologisms in their translation, but some were very awkward. They did not catch on at the time and are on longer used in Chinese, for instance, juwai (neutrality, now zhongli has replaced it), xingfa (natural law, now it is ziran fa), shouling or boliyingtiande (president, now it is zongtong), lüfa or fadulueli (law, now it is falü), fashi or gongshi (judge, now it is faguan (see Chiu 1968; Henderson 1970).

For other translations at the time, the translators also encountered many problems as to how to create new words in Chinese. One of the methods that turned out to be unsuccessful was transliteration for foreign terms, for instance, in Wei Yuan's translation Hai guo tu zhi (Illustrated Treatise on the Maritime Countries), some basic institutional legal terms were transliterated into Chinese, ba li man 巴厘满 (parliament) (Qu 2013; J. Wang 2005; W. Wang 1985). Such transliterated words in Chinese made little sense, and were extremely awkward, carrying no meaning to the Chinese readers. They never caught on or were used (J. Wang 2005). Thus, transliteration as a translation method failed and was soon dropped. Instead, a new and more effective method was found in its place, that is, direct borrowing from the Japanese language.

Around the end of 1800s and the beginning of 1900s, the focus and efforts started to shift to the translation of Western legal works via Japanese which turned out to be an ingenious shortcut. Under the auspices of Shen Jiaben and other officials commissioned by the Qing government as mentioned earlier, translation began to focus on Western laws and legal codes for the purpose of drafting and making Chinese laws. The various laws in different countries in Europe and U.S.A. were translated into Chinese as the blueprint, including laws from the U.K., U.S.A., Germany, France, Russia, and others, but some of the translations were not translated from English or other European language. Instead, they were translated from the Japanese versions which had previously been translated from English or other European languages. Chinese legal scholars, many of whom were trained in law in Japan, made selective use of the Japanese law and legal language, which were modelled on the European civil law. In this process of Chinese translation from the Japanese translations, a large number of legal terms were directly taken or borrowed from Japanese into Chinese as the Japanese language used and still uses many 
Chinese characters ${ }^{8}$. The borrowing to China from Japan was largely successful due to various reasons, including the fact that there was a shared core of linguistic and legal traditions between China and Japan with the latter heavily influenced by Chinese culture before the mid-nineteenth century, the need for modernization of both societies under similar historical circumstances, and the success of the Westernization of Japanese law at the time before China started its modernization and law reform (Hao 1997; Henderson 1970).

Thus, as we have seen, translation of Western laws and borrowing from Japanese enriched the Chinese legal language. Together with the new language, the basic legal science, legal philosophy, legal principles and legal practices and basic legal concepts in Western law including the rule of law, separation of powers, judicial independence, jury, constitutionalism, presumption of innocence, legal person, rights, obligations, among others, were introduced to China for the very first time. Modern Chinese legal system based on Western law and legal thinking and practice were taking shape. The translation activities in introducing Western law to China by reform minded Chinese scholars and jurists were seminal in laying the foundation of modern Chinese law and modern Chinese legal language as we know it today.

\section{Cultural mediation and understanding modern Chinese legal language as a translated language}

There are a number of implications from the foregoing discussion. First, modern Chinese legal language is largely a translated language as we have seen in the forgoing. It developed and evolved rather rapidly within a short period of time thanks to translation of Western laws, and in the process, this was greatly assisted by direct borrowing from the Japanese language.

\footnotetext{
${ }^{8}$ It is noted here that for the borrowing from the Japanese, there was 'reborrowing', as well as 'direct borrowing' from Japan. In most of the cases, it was reborrowing, that is, the Chinese reborrowed the Japanese characters that had been borrowed by the Japanese from the Chinese many centuries earlier. Reborrowing may have contributed to much of the confusion in the minds of the Chinese as to the meaning of the 'newly' created legal words, given that some characters that were originally Chinese were then borrowed to the Japanese, and finally re-imported to China with new referential objects assigned to them in the legal context. Acknowledgments are made here to an *anonymous reviewer for pointing this out.
} 
In a sense, modern Chinese legal language is a hybrid. Translation is a motivating force and empowering medium for reforming and transforming the Chinese society in transition. Translation played and is still playing a vital and indispensable role in the development of modern Chinese legal language.

Secondly, for the English reader of translated Chinese law, even though modern Chinese legal language is a translated language heavily influenced by Western law and terminology, many Chinese legal terms of foreign origin have unfolded a life of their own in the Chinese social, political and legal contexts (Cao 2004) ${ }^{9}$. As we know, translation is never made in or into a vacuum. The act of importation in translation can potentially dislocate or relocate the whole of the target linguistic and cultural structures as it introduces in the target language an alternate existence, a 'might have been' or 'is yet to come' into the substance and historical conditions of the target language and culture, with the foreign sense and its domestication in a new linguistic-cultural matrix (Steiner 1975/1998: 351). George Steiner noted further that no language and no traditional symbolic set of cultural ensemble imports without risk of being transformed (Steiner 1975/1998: 415). Similarly, while translation imports and naturalizes the source language content in the target language, it at the same time simulates and challenges the original of that content in the source language (Steiner, 1975/1998: 351). As suggested, translation involves an encounter, if not a confrontation, between two sets of norms, which correspond to the two codes involved (Toury 1986: 1123). There is the source language code, the target language code and something in between that travels between the source and target language and there are linguistic as well as legal norms. There is 'a perpetual shuffling' back and forth between the source text and target text in the act of translation. Indeed, translated words or texts constitute a third code, arising out of the bilateral

\footnotetext{
${ }^{9}$ In some fundamental ways, the Chinese legal language as a 'translated language' is different from, for instance, the translated language of science between Chinese and European languages when scientific words and concepts were first introduced to China and translated into Chinese, because scientific words and concepts referring to the physical realities were and are the same irrespective it is in Europe or in China and elsewhere. Laws and legal words and concepts are indigenous and often unique to the country, culture and jurisdiction where they are used and are culture bound. However, a situation that may be similar to translated legal language in Chinese is found in the Chinese Buddhist language, largely translating Sanskrit terms and notions, before they were localised in Chinese culture. Acknowledgements are made here to an anonymous reviewer for pointing this out.
} 
consideration of the source and target codes, a new code with new information (Frawley 1984: 161). The source code provides the essential information to be recodified, and the target code provides the parameters for the re-rendering of that information. Translation is a complex de-codification and re-codification process of semiosis, a sign producing activity that effects consequences, not just in language (Cao 2007).

In China's case, the translation of foreign laws has produced consequences beyond the original texts and laws, effecting outcomes in Chinese culture and generating new meanings in Chinese and elsewhere, in a semiotic productive act, a 'dialogic thought development' to borrow the phrase (Kevelson 1988). In its 'afterlife', that is, a work brought to reality by the act and result of translation as is described by Walter Benjamin (1923/2000), the translated law takes on meanings from the two associated sign systems linguistically and culturally, both the West and China. Moreover, the Chinese legal language and its terminology, far from serving as simple equivalents of imported ways of understanding, have often acquired new meanings that can 'creatively alter, extend or even undermine established European conceptions' (Kurtz 2001: 10). In our understanding of Chinese law, we may need to see and learn about 'the multilayered process of translation and appropriation from which these terms have emerged, not merely as deviations from the original Western meanings' (Kurtz 2001: 10). Take for example the legal concept of 'constitution'. The concept and practice of 'constitution' as in constitutional law did not exist in China until around the turn of the twentieth century when it was first introduced from the West.

The term xianfa (constitution) we use in Chinese today, as mentioned earlier, was borrowed from the Japanese phrase translated from the Western notion using Chinese characters (Hao 1997). Separately, xian means order, ordinance, law in classical Chinese, (in Japanese also using the same Chinese character), and $f a$ also means law. They had different meanings from xianfa (constitution) in modern language in both Japanese and Chinese. During the Meiji Restoration period (1868-1914, also called Meiji Renovation or Reform), the Japanese translated and introduced Continental European law and the Western concept of constitutional government. The word xianfa was first used in 1882 in Japan as a new translation for constitution in the Western sense. The Meiji Restoration led to enormous changes in Japan's political and social structure and Japan industrialized and 
adopted many Western ideas and laws including creating a Western style Japanese Constitution that would redefine Japan as a modern nation in 1889. In China, in 1880s to 1990s, Chinese reformers wished to learn from Japan and to create a constitution and constitutional monarchy modelled after the Japanese. In 1908, the Qing government promulgated the Constitution Outline by Imperial Order based on the blueprint of the Japanese Constitution. This is the first time when the word xianfa and xianfa as the country fundamental law came into existence in China.

If we look at the meaning of the word xianfa, although the two characters in xianfa were used in traditional China, as said above, they have different meanings from the xianfa used to refer to constitution. Thus, xianfa could be considered a new semantic form in Chinese, and its referential meaning was based and found in Western constitutional law. This linguistic existence of xianfa was given a conceptual and referential object, a functional equivalence, in the Chinese system, only when constitutional practice was adopted and the first constitution was promulgated in China in the early 1900s and when the concept was incorporated into the Chinese political and legal system. Now xianfa in Chinese has a generic meaning, that is, a constitution is a legal document with supreme legal force, setting out the basic structures of government, and this meaning originated from the Western liberal tradition. But when we talk about the Chinese constitution and Chinese constitutional practice in the People's Republic of China, xianfa specifically refers to the Chinese context as opposed to others, and its referential object is found in China, not in Japan, or Europe or elsewhere. It is commonly acknowledged that the Chinese 'Constitution' differs significantly from constitutions in liberal democratic societies. However, this does not prevent xianfa from being an equivalent to 'constitution', as the basic idea of xianfa in Chinese corresponds to that in English. A core conceptual equivalent meaning exists linking the English and Chinese linguistic signs. It would be an absurdity to suggest that the Chinese xianfa cannot be translated back into English as 'constitution'. The constitutions or constitutional laws in European countries are different. Many legal terms in English and their definitions are not identical in these jurisdictions. In the case of xianfa, they are and should be translated into the corresponding 'constitution', as they share a core semantic and conceptual meaning with the English counterparts. This does not prevent people from agreeing or disagreeing as to whether the constitution or constitutional 
law as practised in China are different or similar to those in a Western liberal democracy (for the discussion of quanli (rights) and its Chinese and English meanings, see Cao (2017)).

Regarding the issue of understanding translated legal terms, after the initial linguistic transfer, it was once remarked, 'a word never - well, hardly ever - shakes off its etymology and formation. In spite of all changes in and extensions of and additions to its meaning, and indeed rather pervading and governing these, there will persist the old idea' (Austin 1970: 201). It is proposed that legal translation is a space of possibilities, an autonomous real of 'cross-cultural events' within which the 'system-bound' of legal concepts and notions deeply rooted in language, history and societal evolution of one country are transformed and integrated into the language of another, and as a result, stratified over the course of time. As said in this special issue, the legal translation process can be seen as constituting the 'Third Space', a space-in-between, which enables other positions to emerge and where all forms of cultures are continually in a process of hybridity, of evolution (see Bhabha 2012), and other authors in this issue), and in this process, 'cultural mediation' is an essential pillar as it opens up a series of promising ways, alternatives, and compromises to create encounters and crossroads between disciplines for practical possibilities in the legal translation process (Wagner 2018; Wagner \& Gémar 2013, 2014a, 2014b). As pointed out, words can take different meanings when injected in a different context, being it political, social, historical, or individual. Concepts thus are always culturally and historically embedded, and the meanings of a term change both diachronically and synchronically according to the various interpretations that people, depending on their particular formation and context (Carrai 2017). It was suggested that idea of translingual practice may be useful, which is understood as a process through which concepts and words are translated, adopted, and appropriated in other languages, and the gradual legitimization of a new word and concept in a given host language takes place in an arena where there are constant struggles of political and ideological nature for asserting different interests (Liu 1995).

For our purpose, despite the seemingly insurmountable conceptual and linguistic gulf, alleged and real, between the Chinese and Western laws and languages, the Chinese interpreters of the late 1800 s and the early 1900s, collectively and individually, interpreted and absorbed an otherwise unfamiliar law in translated Chinese. In modern 
China, through translation and interpretation, new knowledge and new realities were brought into existence. The modernization of Chinese law symbolizes a kind of death and rebirth, that is, both the death and regeneration of ancient Chinese law (He 2004b: 300-302). However, the death of a legal culture or legal order is unlike that physical death of a living being as the ways of thinking and ideas will linger in people's minds and in society, continuing to exert influences in different ways, even if the old laws no longer function; and the new laws and legal order were built and injected into the old system in the last one hundred years or so in China (He 2004b: 300-302). This is particular true with regard to the Chinese legal language. The old Chinese characters from two thousand years ago describing entirely different eras and the now dead system and practices were revived or re-coded and re-engineered so to speak, to signify new and foreign legal concepts, legal thinking and practices. In modern Chinese legal language, the traditional inherited meanings related to law and the more recent introduced foreign meanings are encoded and superimposed.

\section{Conclusion}

In the history of modern China, language and translated language play an important part in the migration of knowledge, across linguistic and temporal boundaries. When new knowledge or information was initially introduced into the Chinese environment, the words that were coined or redefined to carry that knowledge also carry with them potential transforming power. In a little more than one hundred years, the Chinese language absorbed or devoured the nomenclatures of the most diverse branches of Western knowledge whose formation had taken millennia in the Occident (Lackner, Amelung, \& Kurtz 2001: 12 ). These words have created not just new meanings but also new realities in Chinese culture and Chinese law. The translation of foreign laws into Chinese is not a mechanical equation of the abstract and absolute equivalence, not a replica but a developmental stage, 'a further step in the growth of the expressive life to which the first word or text gives birth' (Montgomery 2000: 284). Translation has been a powerful means to create and manage change in modern China. The Chinese people have been constantly engaged in two kinds of translation: translating foreign 
ideas and laws into Chinese in both new and recycled Chinese, and translating traditional Chinese meanings within a new and changed context. Chinese communicative practices are one of translation, of both diachronic and synchronic transfer of significance, and both inside Chinese and between Chinese and Western languages. Chinese 'interpretive horizons' (to borrow Gadamer's phrase) are built on the basis of Chinese and Western discourses, with new meanings and realities are generated on such basis.

\section{References}

Austin, J. L. 1970. Philosophical Papers. Oxford: Clarendon Press. Benjamin, W. 1923/2000. The task of the translator. In L. Venuti (Ed.), The Translation Studies Reader (pp. 15-25). London: Routledge.

Bhabha, H. K. 2012. The location of culture. London: Routledge.

Cao, D. 2004. Chinese law: A language perspective. Aldershot: Ashgate.

Cao, D. 2007. Translating law: Multilingual Matters.

Cao, D. 2017. On the universality of "rights": Absence and presence of "rights" in the Chinese language. Intercultural Pragmatics, 14(2), 277-292.

Cao, D. 2018. Chinese language in law: Code red. Lantham: Lexington Books.

Carrai, M. A. 2017. Translating authority: In search of commensurability between Tianxia world order and Western sovereignty.

Chang, H.-t. u. 1950. The Earliest Phase of the Introduction of Western Political Science into China. Yenching Journal of Social Studies, 5, 1417-1444.

Chiu, H. 1968. The development of Chinese international law terms and the problem of their translation into English. In J. A. Cohen (Ed.), Contemporary Chinese Law Problems and Perspectives (pp. 139-157). Cambridge: Harvard University Press.

Fairbank, J. K. 1940. Chinese diplomacy and the treaty of Nanking, 1842. The Journal of Modern History, 12(1), 1-30. 
Deborah Cao: Translation as a catalyst in the development...

Fish, I. S. 2019. Stop Calling Xi Jinping 'President' It's not actually his title, and it helps legitimize his authoritarian rule. Slate.

Frawley, W. 1984. Prolegomenon to a theory of translation. In W. Frawley (Ed.), Translation: Literary, Linguistic and Philosophical Perspectives (pp. 159-178 ). Cranbury, New Jersey: Associated University Press.

Hao, T. 1997. Zhongguo jindai faxue liuxuesheng yu fazhi jindaihua (China's Returned Law Students from Overseas and Its Law Modernization) Faxue yanjiu (CASS Law Journal), 6, 3-33.

He, Q. 2001. 《万国公法》与清末国际法 (The Elements of International Law in Chinese and International law in the Late Qing Dynasty). Faxue yanjiu (CASS Law Journal), 23(5), 137148.

He, Q. 2004a. The Student Studying Law Science Abroad and Law Science of Modern China Legal Forum, 6(5), 82-90.

He, Q. 2004b. 法律文化史谭 (Studies in the history of legal culture) Beijing: Shangwu yinshuguan.

Henderson, D. F. 1970. Japanese influences on communist Chinese legal language. In J. A. Cohen (Ed.), Contemporary Chinese Law: Research Problems and Perspectives (pp. 158-187). Cambridge: Harvard University Press.

Kevelson, R. 1988. The law as a system of signs. New York: Plenum Press.

Kurtz, J. 2001. Coming to terms with logic: The naturalization of an Occidental notion in China. In M. Lackner, I. Amelung, \& J. Kurtz (Eds.), New terms for new ideas: Western knowledge and lexical change in late imperial China (pp. 147-176). Leiden: Brill.

Lackner, M., Amelung, I., \& Kurtz, J. 2001. New terms for new ideas: Western knowledge and lexical change in late imperial China. Leiden: Brill.

Li，G. 1997. 二十世纪初期的中国法学 Legal Studies in Early Twentieth Century China (in Chinese). Zhongwai faxue (Chinese and Foreign Legal Studies), 2(1), 1-14.

Liu, L. H. 1995. Translingual practice: Literature, national culture, and translated modernity--China, 1900-1937: Stanford University Press.

Martin, W., A.P 1864. Wanguo gongfa (Elements of International Law), trans. Beijing: Chongshiguan. 
Montgomery, S. L. 2000. Science in translation: Movements of knowledge through cultures and time. Chicago: University of Chicago Press.

$\mathrm{Qu}$, W. 2013. 从词典出发: 法律术语译名统一与规范化的翻译史研 究 (Start from dictionaries: Studies on the translation history of harmonization and standardization of translated legal terms. Shanghai: Shanghai renmin chubanshe.

Soo, F. 1989. China and modernization: Past and present a discussion. Studies in Soviet Thought, 38(1), 3-54.

Steiner, G. 1975/1998. After Babel: Aspects of Language and Translation. Oxford: Oxford University Press.

Svarverud, R. 2001. The Notions of 'Power' and 'Rights' in Chinese Political Discourse. In M. Lackner, I. Amelung, \& J. Kurtz (Eds.), New terms for new ideas: Western knowledge and lexical change in late imperial China (pp. 125-146). Leiden: Brill.

Tian, T., \& Li, Z. 2000. 清末翻译外国法学书籍评述 (Commentary on the Chinese Translations of Foreign Legal Works in the Late Qing Dynasty). Zhongwai faxue (Peking University Law Journal), 12(3), 355-371.

Toury, G. 1986. Translation: A cultural-semiotic perspective. In T. Sebeok (Ed.), Encyclopedic dictionary of semiotics (Vol. 2, pp. 1111-1124). Berlin Mouton de Gruyter.

Vattel, E. d. 1863. The Law of Nations, trans. and ed. J. Chitty: New York: AMS Press.

Wagner, A. 2018. Visual Rhetoric as "A Space-in-Between": Semiotic Account of French Official Presidential Photographs Sensing the Nation's Law (pp. 153-172): Springer.

Wagner, A., \& Gémar, J.-C. 2013. Materializing notions, concepts and language into another linguistic framework. International Journal for the Semiotics of Law-Revue internationale de Sémiotique juridique, 26(4), 731-745.

Wagner, A., \& Gémar, J.-C. 2014a. Communication and culture mediation techniques in jurilinguistics. Semiotica, 2014(201), $1-15$.

Wagner, A., \& Gémar, J.-C. 2014b. Jurilinguistique et Juritraductologie-A Collective and Societal Dimension: Multiplicity of Meaning between Sciences and Society, 27 INT'L J. SEMIOT. L. 
Deborah Cao: Translation as a catalyst in the development...

Wang, J. 2005. New Coinage of Legal Vocabulary in Late Qing Dynasty and Impact on Relation with Japan. Journal of Nanjing University, 6, 100-109.

Wang, W. 1985. 林则徐翻译西方国际法著作考略 [An investigation of Lin Zexu's translation of western international law books]. Journal of Sun Yat-sen University, 1, 58-67.

Wheaton, H. 1916. Wheaton's Elements of international law: Stevens and sons, limited.

Wong, J. D. 2018. From the Treaty of Nanking to the Joint Declaration: The Struggle for Equality through State Documents. Law \& Literature, 30(2), 309-329.

Yu, J. 2001. 近代中国法学语词的形成与发展 (Formation and Development of Modern Chinese Legal Language and Terms). Beijing: Zhongguo zhengfa daxue chubanshe. 